\title{
THE STUDY OF PEDESTRIAN'S CONVENIENCE AND PRIVACY TOWARDS PANDANARAN CROSSING BRIDGE CONDITION
}

\author{
Djoko Indrosaptono*, Alfanadi Agung Setiyawan** \\ *) Architectural Department, Faculty of Engineering, UNDIP (Diponegoro \\ University), Semarang \\ **) Architectural Department, Faculty of Engineering, UNDIP (Diponegoro \\ University), Semarang \\ e-mail: djokoindrosaptono@gmail.com
}

\begin{abstract}
One of the urban infrastructures that reflect the development of a city is a Crossing Bridge. The activity of human movement between regions will increase If the city is more developed. Crossing Bridge, which is one of the Street Furnitures, has functions to improve people's mobility safely without distracting the flow of existing vehicles. Crossing Bridges have not been optimally utilized by pedestrians, it can be seen by pedestrian behavior when passing through the highway by jumping over the street barrier. As it happened on the Pandanaran road section in the city of Semarang, this behavior causes the bridge to malfunction and brings up further phenomena such as stairs as a seat and circulating bridges being occupied by homeless people. The purpose of this research is to reveal the connection between the privacy attributes and pedestrian convenience, with the setting conditions of the Pandanaran Crossing Bridge in Semarang, by using a quantitative paradigm approach. The results of the questionnaire in closed form and the Behavioral Mapping method will then be analyzed using descriptive statistical analysis techniques until it will finally be revealed that the lack of property strength on the Crossing Bridges, which is not able to meet the pedestrians' attribute needs, causes some people to choose to cross directly.
\end{abstract}

Keywords: Behavior, Convenience, Privacy, Pedestrian, Crossing Bridge

\section{INTRODUCTION}

Pandanaran street is the busiest road in Semarang City. It is one of many roads that accommodate all kinds of activities such as residential, hotel, restaurant, commercial, and office buildings (see Figure 1). The red color in the picture represents a commercial building, yellow is a residential building, and green is a public space or building. 
The abundance of activities on this road presents how dense pedestrian movement is on the sidewalk. Added with the emergence of activity supports that appear along the Pandanaran sidewalk, making this road segment more colorful and lively (Shirvani, 1985). Supporting activities that appear dominant are street vendors, whereas many as 33 street vendors take advantage of the existing Street Furniture to organize their merchandise stands (Setiyawan, 2020).

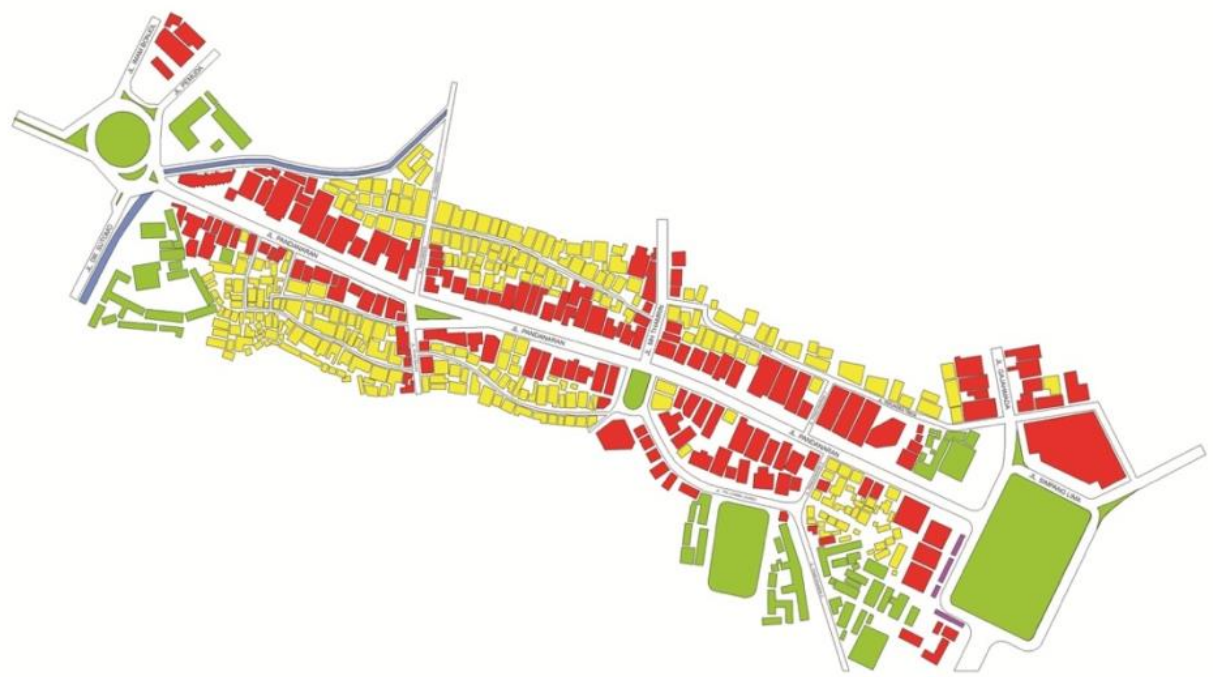

Figure 1. Pandanaran Street Corridor Source: field survey, 2021

To facilitate pedestrian movement, especially to move between sides of the sidewalk safely, there is a pedestrian crossing bridge facility or JPO (Jembatan Penyeberangan Orang). Bridges, especially bridges for vehicles and pedestrians, are the main supporting infrastructure for the daily social and economic sectors of the community (Grigg, 1988). In addition, in the scope of urban design, pedestrian bridges have a function to combine the city's transportation systems as a whole so that pedestrian mobility is more efficient (Wardianto, Budihardjo, \& Prianto, 2012).

The bridge, according to Struyk, Van der Veen \& Soemarsono (1995), is a horizontal construction that serves to connect two separated places while solving obstacles that are underneath in the form of water or traffic. While pedestrian bridges are infrastructures for pedestrians to reach two opposite areas with high traffic underneath (Struyk, Van der Veen, \& Soemarsono, 1995).

If a motorized vehicle driver mixes with pedestrians in one location without any pedestrian crossing bridge $(J P O)$, it can be a dangerous condition because pedestrians are in a very vulnerable position in the event of an accident (Trianingsih, 2014). However, what happened in the case of Pandanaran Crossing Bridge was bridge did not function optimally, because some pedestrians choose to cross via the highway which indirectly endangers themselves and motorists (see Figure 2). 


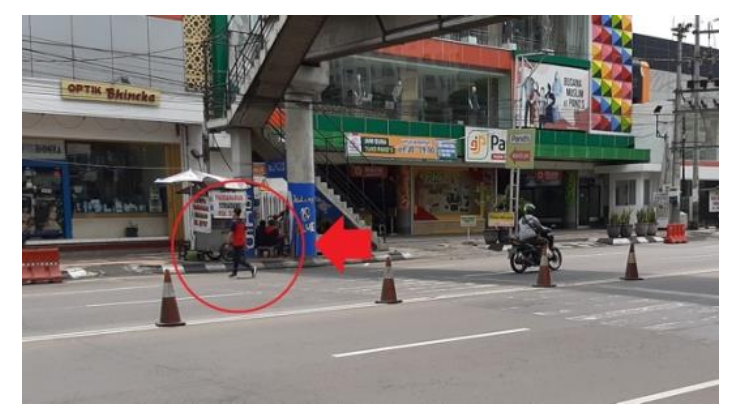

Figure 2. Pedestrian Crossing the Highway Source: field survey, 2021

Because the bridge does not function properly, it causes a further phenomenon as a result, namely the function conversion of the stairs as a seat and the bridge circulation area which is used as a place where the homeless life (see Figure 3).

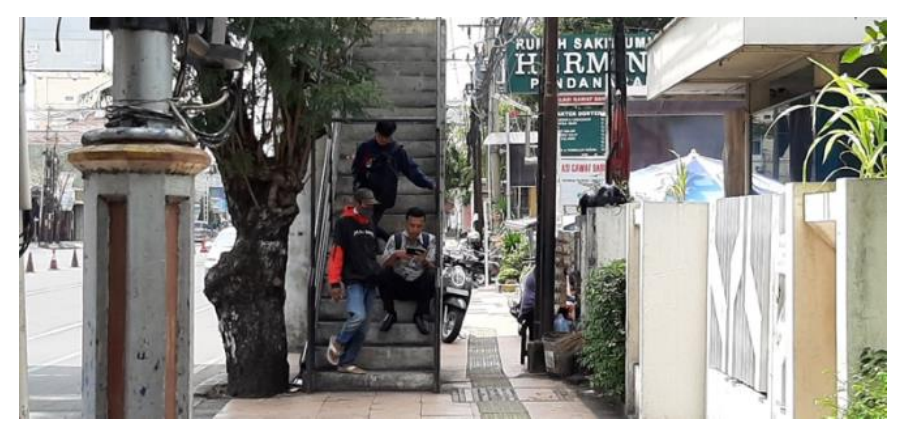

Figure 3. Turning Stairs Function into Seating Area Source: field survey, 2021

Based on direct observations at Pandanaran Crossing Bridge on January 12, 2021, at 09.00 to 10.00 , it was found that 55 pedestrians crossed from the north side to the south side of the sidewalk or vice versa, either through the JPO or through the street. It is suspected that the lack of property strength in the JPO is not able to meet the needs of pedestrian attributes, causing some pedestrians to choose to cross via the street. This research aims to reveal the relationship between the attributes of pedestrian comfort and privacy, with the setting conditions of Pandanaran Crossing Bridge.

\section{THEORY / RESEARCH METHODS}

Property means the character of an object that has different powers in each person. For example, a shady tree has a strong magnet to be used as a place to wait for a bus for prospective passengers, but not for pedestrians who pass by because it becomes a barrier to their steps (must go around the tree). The arrangement of objects and their properties in the settings will provide stimulation to the user, starting from sensing, assimilation by the mind, and then explained based on the experience of each individual (Sarwono, 1992). 
The assimilation above is called Perception, which forms a measure of the properties that evoke the stimulation of the users of the space, either through patterns or interpretations (Walgito, 1994). Forwarded by Bell, Fisher \& Loomis (2001), perception then creates an impact on the surroundings which is called Attitude according to the theory in Figure 4 below.

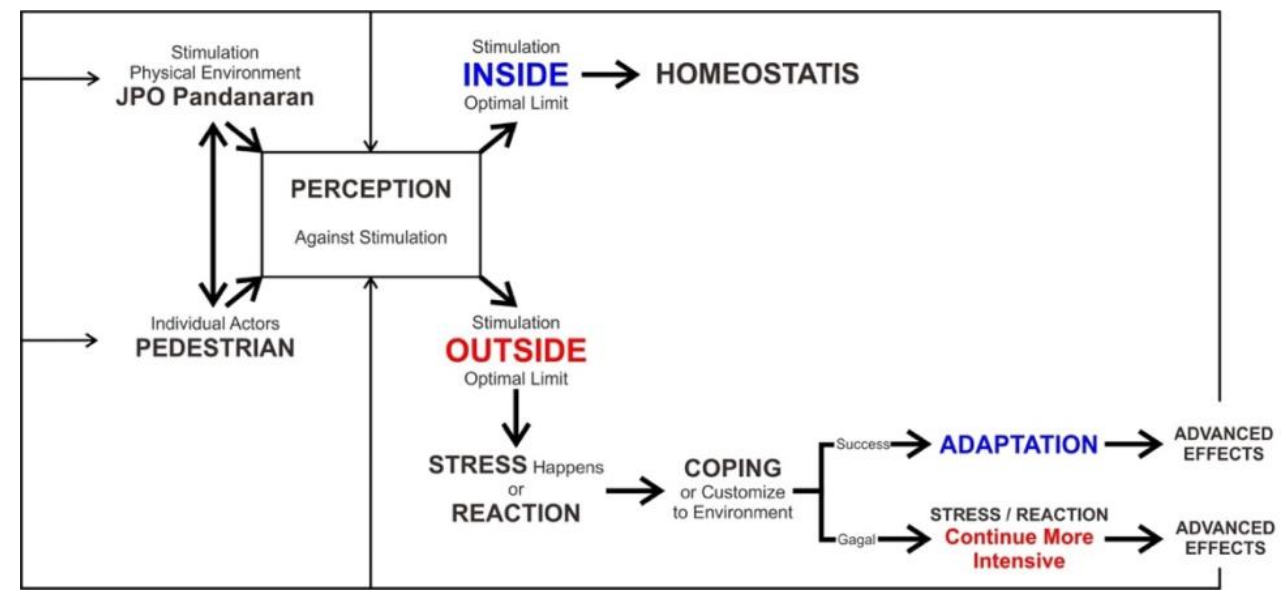

Figure 4. The Theory of Eclectic Model

Source: (Bell et al., 2001)

The theory above explains that human interaction with environmental settings begins with a physical contact process between individual actors and objects or properties in the surrounding environment. In this study, the individual is a pedestrian while the object property is Pandanaran Crossing Bridge. The pedestrian bridge object appears with all its benefits, and pedestrians appear with their character. Individual character is interpreted as an internal aspect in the form of individual motivation, individual interests, goals, interests, and expectations of individuals (Atkinson, 1983). From individual human contact with objects in the surrounding environment, will result in the perception of these objects. If the perception is within optimal limits, it can be called a homeostatic state. Homeostasis is a state of complete balance because it gives the most pleasant feeling. Conversely, if the perception exceeds the optimal limit, it will cause stress so that humans carry out adjustments to the environment which is commonly called "coping".

According to Bell et al. (2001), there are two possibilities in adjusting to the environment, namely:

1. Successful, able to make adjustments or adaptations (environmental conditions will adjust to individuals). The adaptation itself has three models (Altman, 1975), changing environmental conditions to be in sync with desire/adaptation by reaction, changing human behavior to be in harmony with the environment/adaptation by adjustment, and running or moving away from the environment/adaptation by withdrawal.

2. Failed, causing prolonged stress. Human character in the form of variables: individual motivation, individual interests, individual expectations, individual values, and attitudes, will synergize each other with the environment which then 
creates the individual's behavior (Lewin, 1951). Then behavioral phenomena are interpreted as a form of human relations, both individuals and organizations, with the setting of their physical environment (Weisman, 1981). This concept is in line with the theory of the Environmental Behavioral System Model (see Figure 5).

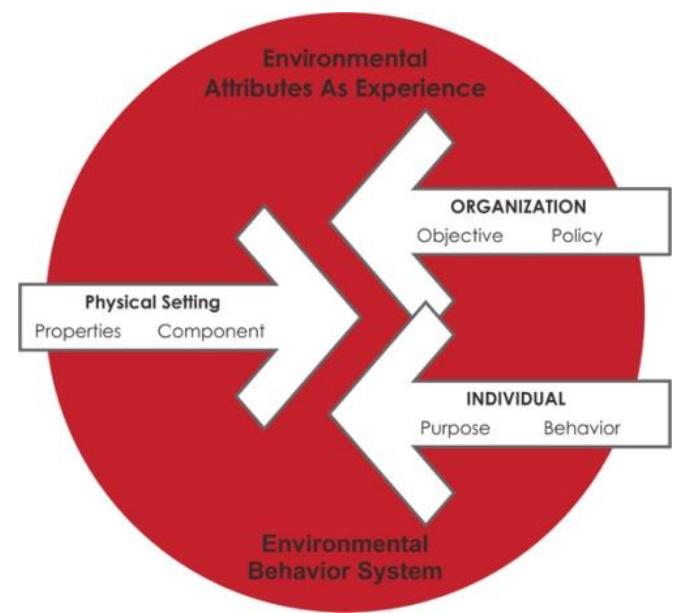

Figure 5. Environmental Behavior System Source: (Weisman, 1981)

The interaction between an individual or organizational behavior in its physical setting according to the theory above will produce an environment with good quality that is considered a unique experience by humans and is called an attribute. Then, the attributes are further classified in the taxonomy, including comfortability, privacy, crowdedness, accessibility, visibility, adaptability, sociability, sensory stimulation, legibility, activity, control, and meaning (Windley \& Scheidt-, 1980).

Determination of the attributes itself cannot be arbitrary but based on the setting of the physical environment and human behavior around it. The word "setting" means the container of physical space in which one's daily habits are contained (Haryadi \& Setiawan, 2010). According to Sarwono (1992), the setting is defined as the arrangement of an environment/layout that can affect human behavior, in other words, in the same place, human behavior can be different if the order is different. The setting is also interpreted as the location of human activities (Rapoport, 1977).

To make it easier to understand the correlation between behavior and the environment, as well as to obtain relevant attributes, a concept of Reconceptualization of the Physical Environment is used, namely by looking at the nature of the environment followed by a sketch of meaning (Archea, 1977). The sketch of the meaning in question is Behavior Mapping, one of which is Person-Centered Mapping, which is observing the flow of human movement in the area of observation (Laurens, 2004).

\section{Comfort Attribute}

The idea of comfort is very difficult to describe because it is a subjective assessment of each individual (Oborne, 1995). Meanwhile, according to Gerungan (2000), 
comfort is an environmental condition that is suitable for sensing and tends to help performance in everyday life.

In this case, comfort is limited by sensory comfort and the dimensions of the stairs issued by Bina Marga (Directorate General of Highways) as a standard reference.

It is stated that the standard pedestrian bridge $(J P O)$ is as follows:

1. The height of the lower threshold of the pedestrian bridge is 4.6 meters (if the road is not passed by double-decker buses), 5.1 meters (if the road is passed by doubledecker buses), and 6.5 meters if the train line is below it.

2. The spacious width dimension for the pedestrian path is 2 meters.

3. The height of the stairs (Optrade) is a minimum of $15 \mathrm{~cm}$ and a maximum of 21.5 $\mathrm{cm}$.

4. The width of the stairs (Antrede) is at least $21.5 \mathrm{~cm}$ and a maximum of $30.5 \mathrm{~cm}$.

For the number of steps and their height, it is determined based on the planned floor height of the bridge (Direktorat Jenderal Bina Marga, 1995).

\section{Privacy Attribute}

Privacy is a sense of solitude for each individual who does not want to be disturbed (Sarwono, 1992). Meanwhile, according to Altman in Prabowo (1998), privacy is a multi-mechanical process. This means that each individual has many ways to get that sense of solitude (Prabowo, 1998). Including by:

a. Personal space

Personal space is defined as a behavioral process to achieve a level of personal privacy. The character of personal space is in the form of virtual boundaries that other people may enter. Personal space is always attached to each individual in everyday life.

b. Territorial

Territory formation is another behavioral process to get certain conditions of privacy. If the process of personal space does not show a clear boundary, then the territoriality of the boundary is real with a relatively fixed place. Territoriality relates to a person's ownership rights to certain geographical conditions.

c. Verbal communication

Verbal communication is the behavior of saying something to others, without forgetting the ethics of politeness and as far as other people can relate to it.

d. Non-verbal communication.

Non-verbal communication is done by expressing facial expressions or certain body movements.

\section{Research Methods}

The strategy of obtaining numerical data (statistics) regarding pedestrian perceptions of the condition of Pandanaran Crossing Bridge uses a closed questionnaire containing independent and dependent variables. The independent variables are perceptions of motives, interests, and expectations (see Table 1). 
Table 1. Independent Variable

\begin{tabular}{|c|c|c|}
\hline $\begin{array}{c}\text { Independent } \\
\text { Variable } \\
\end{array}$ & Indicator & Benchmark \\
\hline \multirow{6}{*}{$\begin{array}{l}\text { Pedestrian's } \\
\text { perception } \\
\text { of the } \\
\text { existence of } \\
\text { Crossing } \\
\text { Bridge as a } \\
\text { movement } \\
\text { facility }\end{array}$} & \multirow{2}{*}{ Motives } & 1. Crossing Through Crossing Bridges is Safer \\
\hline & & 2. Crossing Other Than Crossing Bridges Faster \\
\hline & \multirow{2}{*}{ Interests } & 1. Crossing Bridge as Moving Facility Only \\
\hline & & 2. Using Crossing Bridge to Reach Public Transportation \\
\hline & \multirow{2}{*}{ Hopes } & $\begin{array}{l}\text { The Crossing Bridge will soon be Changed to Make it } \\
\text { More Comfortable to Walk on }\end{array}$ \\
\hline & & 2. This Crossing Bridge is Maintained and Kept Clean \\
\hline
\end{tabular}

Meanwhile, the dependent variable is the attribute that is determined based on the setting conditions, namely Convenience and Privacy (see Table 2).

Table 2. Dependent Variable

\begin{tabular}{|c|c|c|}
\hline $\begin{array}{c}\text { Dependent } \\
\text { Variable }\end{array}$ & Indicator & Benchmark \\
\hline \multirow{8}{*}{$\begin{array}{l}\text { Attributes } \\
\text { Researched } \\
\text { on } \\
\text { Pandanaran's } \\
\text { Crossing } \\
\text { Bridge }\end{array}$} & \multirow{4}{*}{ Convenience } & a. Climbing the Stairs Smoothly \\
\hline & & b. Rest for a while at the Bordes While Climbing the Stairs \\
\hline & & $\begin{array}{l}\text { Walking Behind the Shadow of a Crossing Bridge's } \\
\text { advertisement }\end{array}$ \\
\hline & & b. Free Walk Along the Crossing Bridge \\
\hline & \multirow{4}{*}{ Privacy } & a. Walk as Usual When You Pass in the Middle \\
\hline & & b. Leaning Aside When You Pass in the Middle \\
\hline & & $\begin{array}{l}\text { Saying "Excuse Me/Permisi" When Passing People } \\
\text { aitting on Stairs }\end{array}$ \\
\hline & & b. Climbing the Stairs As Usual \\
\hline
\end{tabular}

Source: Developed from Weisman, 1981 and Windley \& Scheidt, 1980

Behavior mapping data, which is the process of mapping human behavior with repetitive patterns and rhythms, is used to support statistical data (B. Sommer \& Sommer, 1991). One of them is in the form of Person-Centered Mapping which in this study aims to describe Pedestrian Behavior based on perceptions of the attributes of Comfort and Privacy as a result of the environment. In practice, according to Laurens (2004), behavior mapping activities are limited by a period or time budget to show the effectiveness of activities. The agreed time range is $09.00-10.00$. The data obtained were then analyzed by statistical descriptive analysis methods and interpreted. 


\section{RESULTS AND DISCUSSION}

Statistical data generated from pedestrians' perceptions of Pandanaran Crossing Bridge are as follows (see Figure 6).

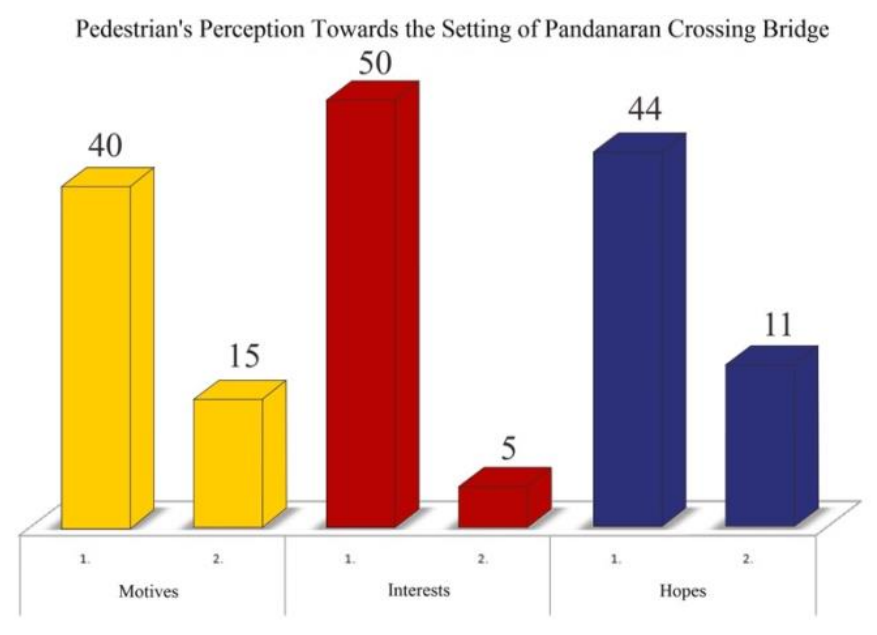

Figure 6. Pedestrian's Perception Data Source: field survey, 2021

From this histogram image, it shows the perception of Motive $1 \rightarrow$ Crossing Through Crossing Bridges is Safer, by 40 people with a percentage of $73 \%(\mathrm{~N}=55)$, while Motive $2 \rightarrow$ Crossing Other Than Crossing Bridges Faster, by 15 people with a percentage of $27 \%(\mathrm{~N}=55)$.

For Interests $1 \rightarrow$ Crossing Bridge as Moving Facility Only, there were 50 people with a percentage of $91 \%(\mathrm{~N}=55)$, while Interest $2 \rightarrow$ Using Crossing Bridge to Reach Public Transportation, were 5 people with a percentage of $9 \%(\mathrm{~N}=55)$.

Regarding Hopes $1 \rightarrow$ The Crossing Bridge will soon be Changed to Make it More Comfortable to Walk on, by 44 people with a percentage of $80 \%$ ( $\mathrm{N}=55$ ), while Hopes $2 \rightarrow$ This Crossing Bridge is Maintained and Kept Clean, by 11 people with a percentage of $20 \%(\mathrm{~N}=55)$.

From the observation data above, it can be concluded that the highest pedestrian perception of the pedestrian bridge is as follows:

1. From the Motives, pedestrians have the perception of crossing through the bridge is safer than directly crossing the highway.

There were 40 people in 1 hour, choosing to cross via the pedestrian bridge. While the rest chose to cross directly through the highway with irregular patterns (see Figure 7). 


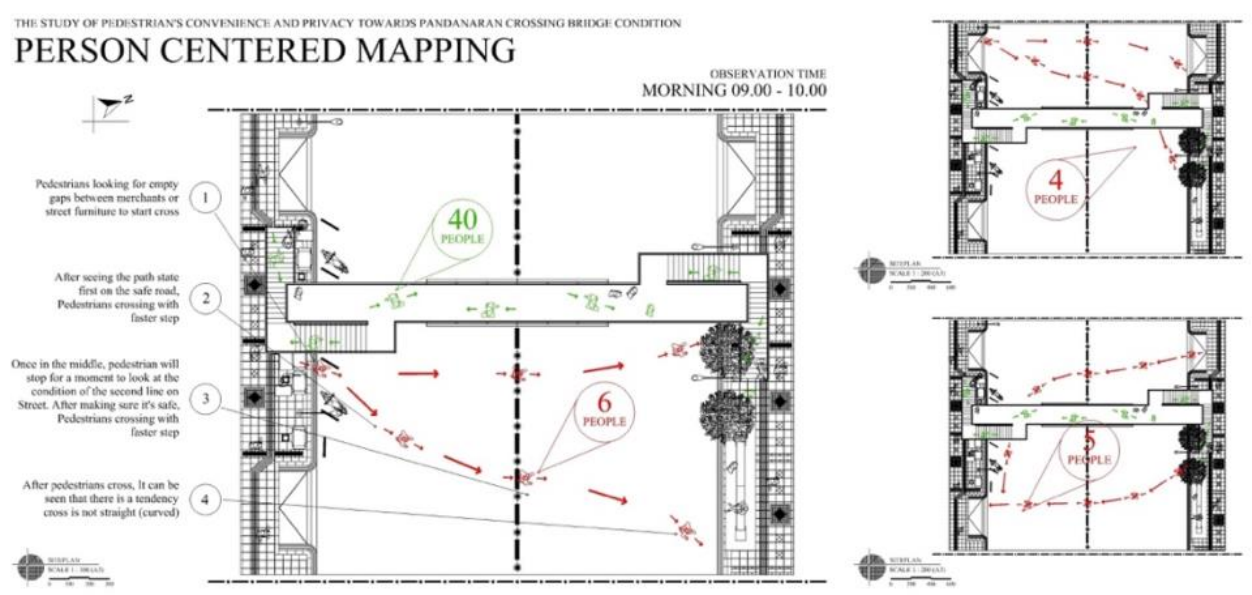

Figure 7. Pedestrian's Motives Mapping Source: field survey, 2021

2. From the Interest, pedestrians use pedestrian bridges to move rather than to reach public transportation stop facilities. Fifty people were crossing the pedestrian bridge to move to another place but the bus stop (see Figure 8).

3. From the Hopes, pedestrians hope that the pedestrian bridge is changed to make it more comfortable to pass.

\section{PERSON CENTERED MAPPING}

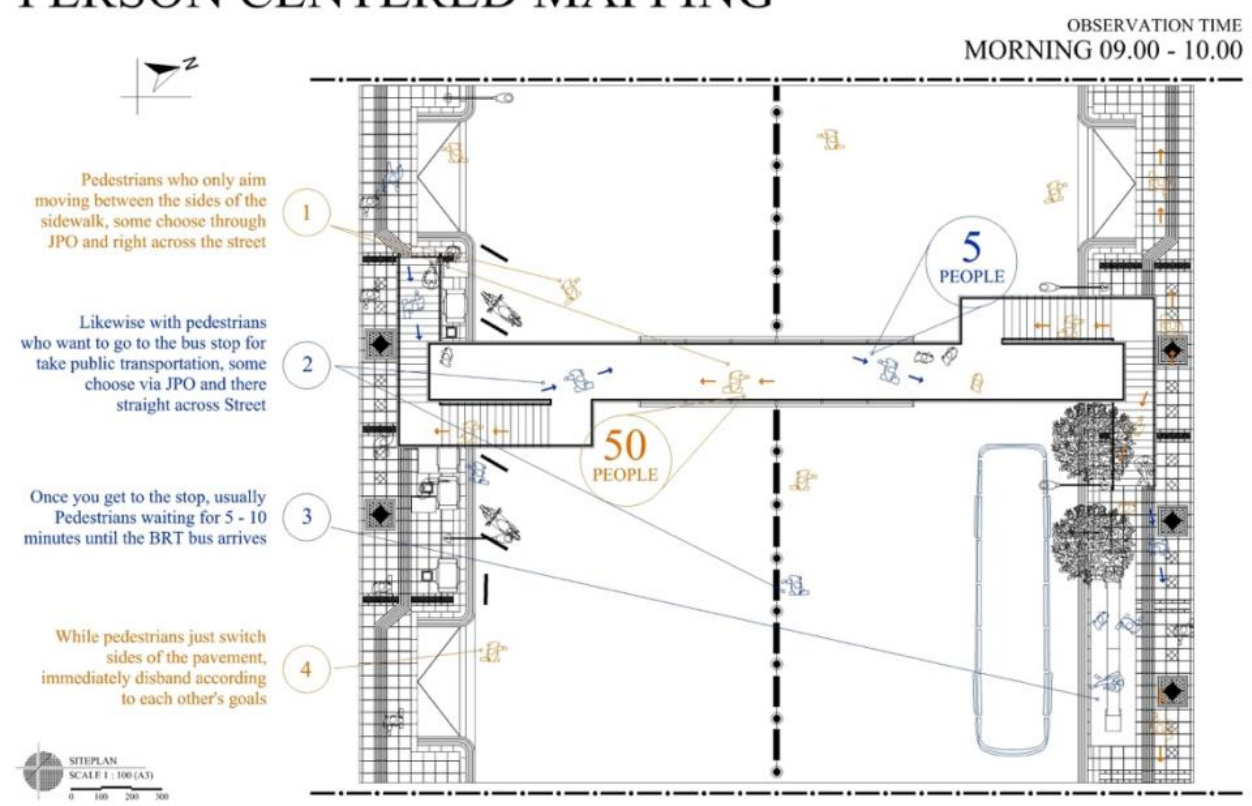

Figure 8. Pedestrian's Interests Mapping Source: field survey, 2021 


\section{Pedestrian Attribute Data}

Meanwhile, statistical data generated from pedestrian attributes are as follows (see Figure 9).

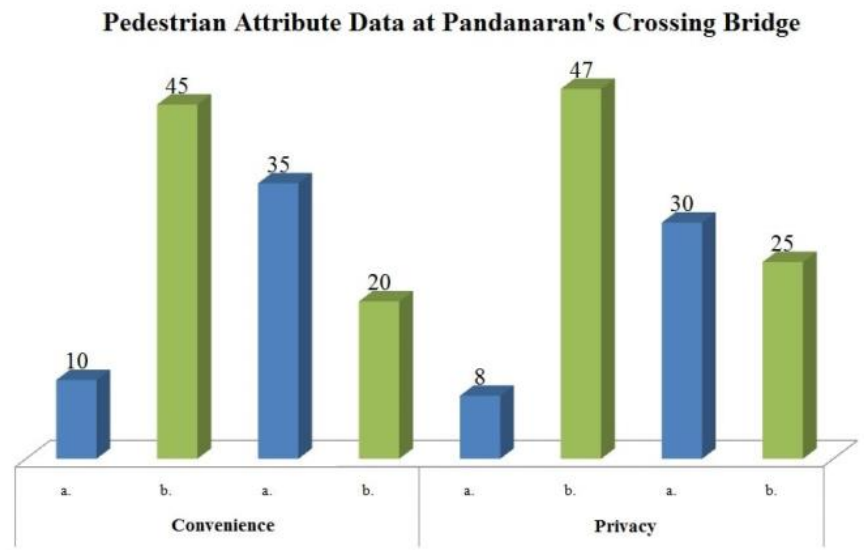

Figure 9. Pedestrian's Attribute Data Source: field survey, 2021

\section{Privacy Attribute}

The histogram graph above shows the first Privacy attribute showing that 47 of 55 pedestrians $(85 \%)$ will turn their bodies sideways when passing in the middle of the bridge. The narrowness of the bridge circulation space, which width is only 1.8 meters, makes pedestrians have to turn their bodies sideways. It is a form of nonverbal communication that can be done by humans because they feel that their privacy is disturbed (see Figure 10).

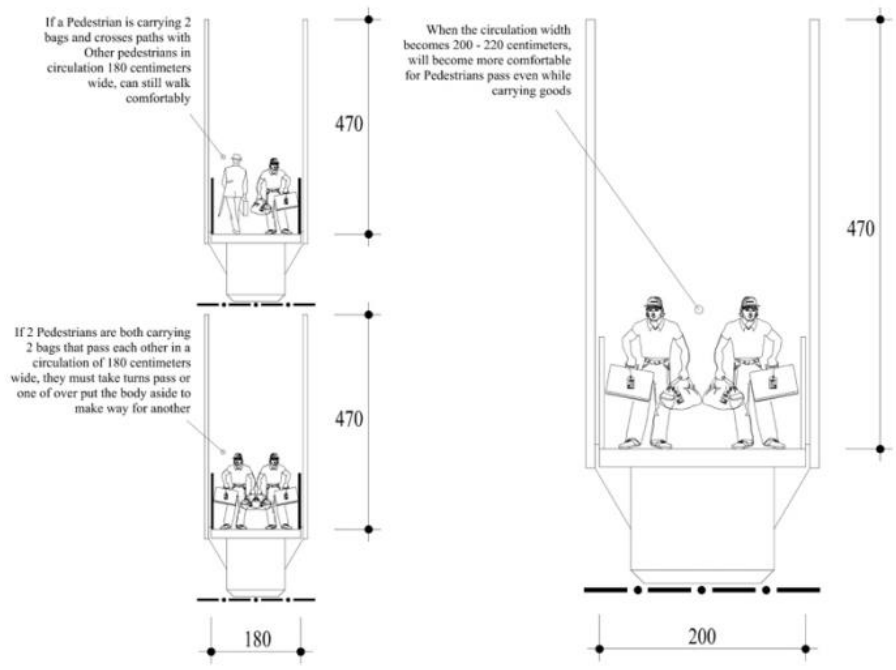

Figure 10. Pedestrian's 1st Privacy Attribute Source: field survey, 2021 
Then the second Privacy attribute is that if there are people who use the stairs to sit, pedestrians will say "excuse me" when passing the person sitting, showing 30 people or with a percentage of $55 \%$ of 55 people.

The function switching of the stairs into a sitting room (see Figure 3) causes pedestrians to feel the need to say "excuse me" because they feel it fulfills the ethics of politeness. This is a form of verbal communication that can be done by humans when they feel their privacy is disturbed (see Figure 11).

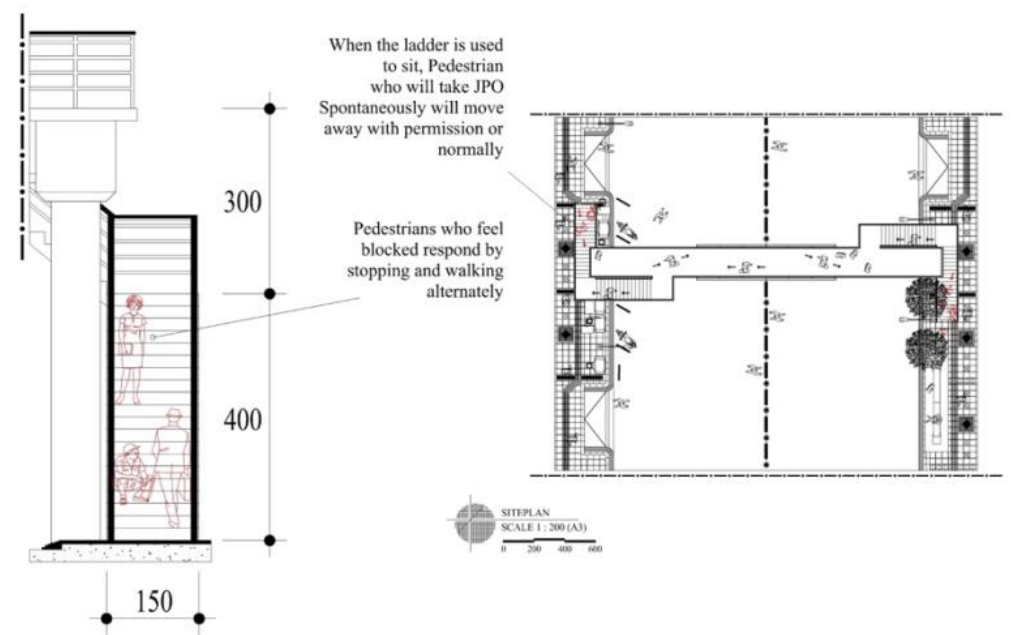

Figure 11. Pedestrian's $2^{\text {nd }}$ Privacy Attribute Source: field survey, 2021

\section{Comfort Attribute}

The previous histogram (see Figure 7), shows the first Convenience attribute that 45 of 55 pedestrians $(82 \%)$ stop for a moment at the stair landing when climbing the stairs. The non-standard trade height is up to $20 \mathrm{~cm}$, causing pedestrians to tired of climbing the stairs (see Figure 12).
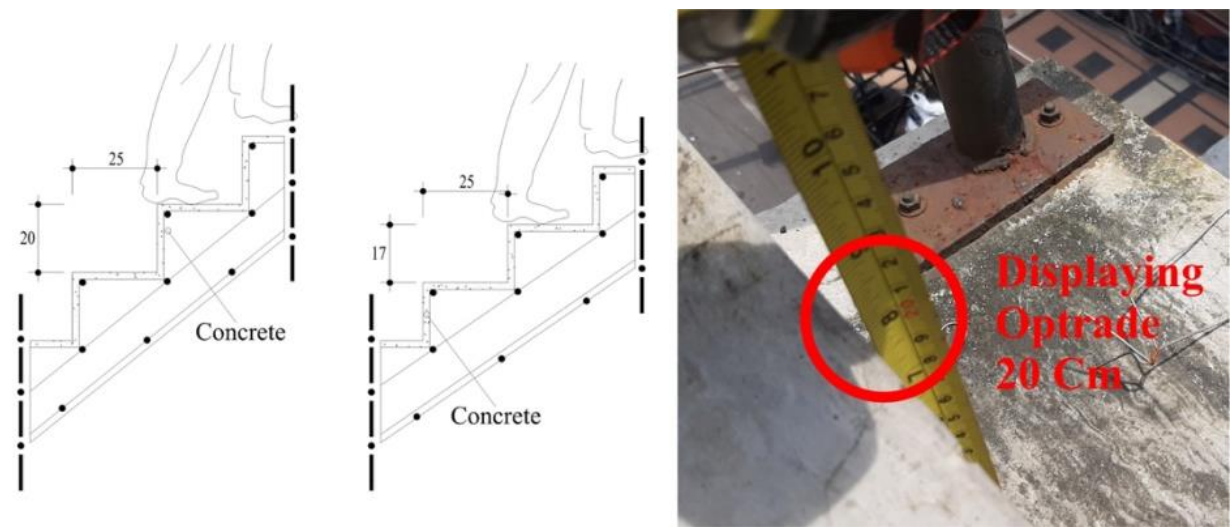

Figure 12. Pedestrian's $1^{\text {st }}$ Convenience Attribute Source: field survey, 2021 
Then for the second Convenience attribute shows that 35 of 55 pedestrians (64\%) choose to walk behind the shadow of the bridge billboard. The absence of top shade causes direct sunlight to enter the bridge circulation (see Figure 13).

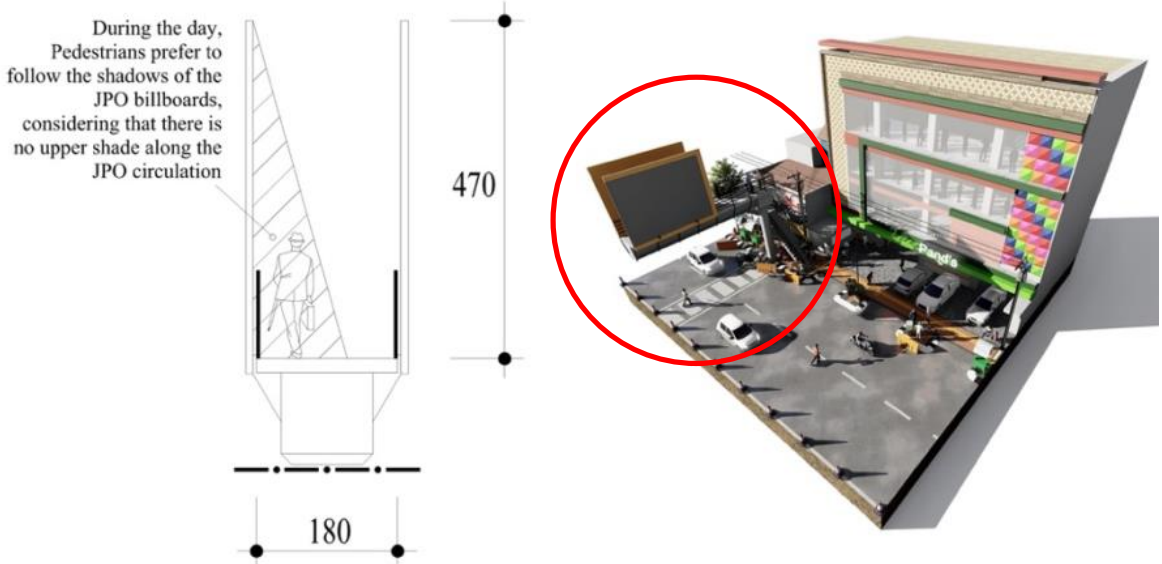

Figure 13. Pedestrian's $2^{\text {nd }}$ Convenience Attribute Source: field survey, 2021

Therefore, pedestrians who pass pedestrian bridges tend to walk following the shadows from the billboards so they do not suffer from the heat.

\section{CONCLUSION}

Based on the analysis conducted, it can be concluded that there is a relationship or correlation between the motives, interests, and expectations of pedestrians in the setting of Pandanaran Crossing Bridge with the attributes of comfort and privacy. In its current condition, it can be proved that these two attributes are indeed not fulfilled which causes some people to choose to cross directly on the street instead of using this pedestrian bridge. The lack of fulfillment of the two attributes are as follows:

\section{Comfort Attribute}

1. The "Optrade" height, which reaches $20 \mathrm{~cm}$, makes pedestrians who climb the stairs feel uncomfortable and get tired quickly, so they need a short break at the stair landing.

2. The absence of top/roof shading causes heat from direct sunlight to enter the circulation area of the bridge.

\section{Privacy Attribute}

1. The non-standard circulation width, which is only 1.8 meters, causes tightness.

2. With the less-optimal function of the pedestrian bridge, another follow-up phenomenon arises, namely the function-shifting of the stairs as a sitting area. 
As for some recommendations for the design of pedestrian bridges that can be done, including (1) Paying attention to the attributes that affect the use effectiveness of pedestrian bridges; (2) Implementing a universal design, which the result can be used by everyone; (3) Maintenance and supervision of pedestrian bridge facilities to function optimally; (4) Location determination of pedestrian bridges that are integrated with other city facilities such as public transportation stops.

\section{REFERENCES}

Altman, I. (1975). The Environment and Social Behavior: Privacy, Personal Space, Territory, Crowding. California: Brooks / Cole Publishing Company.

Archea, J. (1977). The Place of Architectural Factors in Behavioral Theories of Privacy. Journal of Social Issues, 33(3), 116-137.

Atkinson, R. L. (1983). The Hidden Dimension. New York: New York Doubleday.

Bell, P. A., Fisher, J. D., \& Loomis, R. J. (2001). Environmental Psychology. Philadelphia: WB Saunders Company.

Direktorat Jenderal Bina Marga. (1995). Tata Cara Perencanaan Jembatan Penyeberangan untuk Pejalan Kaki di Perkotaan (No.027/T/B). Jakarta: Direktur Bina Teknik.

Grigg, N. S. (1988). Infrastructure, Engineering, and Management. Australia: John Wiley \& Sons.

Haryadi, \& Setiawan, B. (2010). Arsitektur, Lingkungan dan Perilaku. Yogyakarta: Gadjah Mada University Press.

Laurens, J. M. (2004). Arsitektur dan Perilaku Manusia. Jakarta: Grasindo.

Lewin, K. (1951). Field Theory in Social Science. New York: Harper and Brothers.

Oborne, D. (1995). Ergonomic at Work: Human Factors in Design and Development. West Sussex: John Wiley \& Sons.

Prabowo, H. (1998). Pengantar Psikologi Lingkungan. Jakarta: Gunadarma.

Rapoport, A. (1977). Human Aspect of Urban Form. Oxford: Pergamon Press.

Sarwono, S. W. (1992). Psikologi Lingkungan. Jakarta: Gramedia Widiasarana Indonesia.

Setiyawan, A. A. (2020). PERSEPSI ATRIBUT PEDAGANG KAKI LIMA TERHADAP PEMANFAATAN TROTOAR PANDANARAN. ARTEKS : Jurnal Teknik Arsitektur, 5(2), 287-296.

Shirvani, H. (1985). Urban Design Process. New York: Van Nostrand Reinhold.

Sommer, B., \& Sommer, R. (1991). A Practical Guide To Behavioral Research Tools and Techniques. New York: Oxford University Press.

Struyk, H., Van der Veen, K., \& Soemarsono. (1995). Jembatan. Jakarta: PT. Pradnya Paramita.

Trianingsih, L. (2014). Analisis Perilaku Pejalan Kaki Pada Penggunaan Fasilitas Penyeberangan Di Sepanjang Jalan Kawasan Malioboro Yogyakarta. Inersia, 10(2), 106-121.

Walgito, B. (1994). Pengantar Psikologi Umum. Yogyakarta: Andi Offset.

Wardianto, G., Budihardjo, E., \& Prianto, E. (2012). TUNTUTAN ATRIBUT PERSEPSI PEJALAN KAKI PADA PENGGUNAAN JEMBATAN PENYEBERANGAN DI JATINGALEH SEMARANG. Dinamika TEKNIK SIPIL, 12(2), 194-200.

Weisman, G. D. (1981). Modeling Environment Behavior System. A Brief Note. Journal of Man-Environment Relations, 32-41. 
Indrosaptono, Setiyawan: THE STUDY OF PEDESTRIAN'S CONVENIENCE AND PRIVACY TOWARDS PANDANARAN CROSSING BRIDGE CONDITION

Windley, P. G., \& Scheidt-, R. J. (1980). THE WELL-BEING OF OLDER PERSONS IN SMALL RURAL TOWNS: A TOWN PANEL APPROACH. Educational Gerontology, 5, 355-373. https://doi.org/10.1080/0360127800050403 